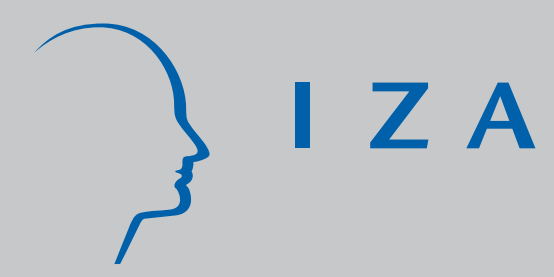

IZA DP No. 3870

Welfare and Employment: A European Dilemma?

Werner Eichhorst

Anton Hemerij ck

December 2008 


\title{
Welfare and Employment: A European Dilemma?
}

\author{
Werner Eichhorst \\ $I Z A$
}

\author{
Anton Hemerijck \\ Netherlands Scientific Council for Government Policy \\ and Erasmus University
}

\section{Discussion Paper No. 3870 \\ December 2008}

\author{
IZA \\ P.O. Box 7240 \\ 53072 Bonn \\ Germany \\ Phone: +49-228-3894-0 \\ Fax: +49-228-3894-180 \\ E-mail: iza@iza.org
}

\begin{abstract}
Any opinions expressed here are those of the author(s) and not those of IZA. Research published in this series may include views on policy, but the institute itself takes no institutional policy positions.

The Institute for the Study of Labor (IZA) in Bonn is a local and virtual international research center and a place of communication between science, politics and business. IZA is an independent nonprofit organization supported by Deutsche Post World Net. The center is associated with the University of Bonn and offers a stimulating research environment through its international network, workshops and conferences, data service, project support, research visits and doctoral program. IZA engages in (i) original and internationally competitive research in all fields of labor economics, (ii) development of policy concepts, and (iii) dissemination of research results and concepts to the interested public.
\end{abstract}

IZA Discussion Papers often represent preliminary work and are circulated to encourage discussion. Citation of such a paper should account for its provisional character. A revised version may be available directly from the author. 
IZA Discussion Paper No. 3870

December 2008

\section{ABSTRACT}

\section{Welfare and Employment: A European Dilemma?}

The majority of the Member States of the European Union have undertaken remarkably comprehensive welfare and labor market reforms in the years since the 1990s. Many of these reforms, however, have not followed the conventional retrenchment and deregulation recipes, but rather took a liking to social pacts, activation, active ageing/avoidance of early retirement, part-time work, lifelong learning, parental leave, gender mainstreaming, flexicurity (balancing flexibility with security), reconciling work and family life. At first sight, these reforms seem to have resulted in relatively robust employment growth, especially for women and more recently older workers. European economic integration has fundamentally recast the boundaries of national systems of employment regulation and social protection, both by constraining the autonomy for domestic policy options but also by opening opportunities for EU-led social and employment coordination and agenda setting.

JEL Classification: J21, J58

Keywords: $\quad$ labor market reforms, European integration, welfare states

Corresponding author:

Werner Eichhorst

IZA

P.O. Box 7240

D-53072 Bonn

Germany

E-mail: eichhorst@iza.org 


\section{THE REFORM CAPACITY OF THE SEMI-SOVEREIGN EUROPEAN WELFARE STATE}

Is the European welfare state fit for globalization? This question has haunted European policy makers for over a decade. Sluggish growth and elusive job creation round the turn of the new millennium have given way to a fierce ideological battle between different socioeconomic "models", triggering political strife and antagonistic advocacy coalitions. A casual glance at the 2005 French referendum campaign over the Constitutional Treaty reveals the contest between two polarized positions. The French version of the European social model was pitted against a false stereotype of the 'Anglo-Saxon' model of capitalism, allegedly a "free market without a safety net", producing high levels of poverty and inequality. Politicians across the Channel, like Tony Blair in his address to the European Parliament on J une 23, in turn posed the rhetorical question: "What type of social model is it that has 20 million unemployed?"

In the early 1990s, the OECD received a mandate to examine the labour market performance of its member countries. The OECD J obs Strategy, published in 1994, launched a critical attack on the 'dark side' of double-digit unemployment of many of its European OECD members. Hovering around ten percent with little signs of improvement (OECD, 1994) unemployment rates in the large economies of France, Germany, and Italy were twice as high as in the USA. The employment rate was about twelve points below the USA. The OECD economists argued that Europe's generous welfare states, with their overprotective job security, high minimum wages and generous unemployment insurance, heavy taxation, and their overriding emphasis on coordinated wage bargaining and social dialogue, had raised the costs of labor above market clearing levels. Moreover, strong 'insider - outsider' cleavages with unfavorable employment chances for the young, women, the old and the unskilled, prevented the rigid European labor markets from producing employment rates, on a par with the US, the UK or New Zealand. The OECD thus portrayed the fundamental dilemma of Europe's mature welfare states in terms of a trade-off between welfare equity and employment efficiency. The policy recommendations that naturally followed from this analysis included retrenchment of unemployment compensation, deregulation of job protection legislation, reduction of minimum wages, decentralization of wage bargaining, and lower taxation.

The OECD J obs Strategy shocked the welfare-friendly mainland European policy elites, social-democratic and Christian democratic parties and trade unions of different political colors. In the course of the 1990s, the slow, fragmentary and half-hearted implementation of 
the recommendations of the OECD J obs Strategy came to be attributed to political deadlock and opposition and trade union protest. It was argued that serious reform in mature welfare states proved politically unrewarding because losses are concentrated and resisted by vested interests, while the gains are spread out only thinly. As a result, deadlock prevailed in spite of unsatisfactory employment performance and mounting social and political discontent. The European welfare state, as Paul Pierson put it, proved to be an 'unmovable object' (Pierson, 1998).

But is this image of a 'frozen welfare status quo' in the face of a severe employment crisis truly correct? Are European political economies only fit for globalization if and when they give up on its postwar commitment of generous and encompassing welfare provision? Are mainland European welfare states really that ossified and resilient, unable to improve their employment record? We believe not. The majority of the Member States of the European Union (EU) have undertaken remarkably comprehensive welfare and labor market reforms in the years since the 1990s. Many of these reforms, however, have not followed the conventional retrenchment and deregulation recipes of the OECD, but rather took a liking to social pacts, activation, active ageing/ avoidance of early retirement, part-time work, lifelong learning, parental leave, gender mainstreaming, flexicurity (balancing flexibility with security), reconciling work and family life. At first sight, these reforms seem to have resulted in relatively robust employment grouth, especially for women and more recently older workers. While in 1997 the EU15 employment rate trailed 12.8 percentage points behind the US, by 2005 the gap was more than halved to 6.3 percent. Mirroring the improvement in employment performance, standardized unemployment rates in fell to 7.1. percent in the eurozone economies, but as the chapter by Saraceno shows long-term unemployment remained a serious problem.

To say that European welfare states are far from sclerotic, is not to say that they are all in good shape. But rather than extrapolating policy recipes from recent economic performance, urging European OECD members to recast their social market economies along the lines of American capitalism, a more illuminating way to understand recent reform dynamics is to contextualize existing social policy repertoires and reform dynamics in the face of the changing economic and technological challenges and evolving social and demographic structures. Today four sets of challenges confront policy makers with the imperative to redirect the welfare effort, to redesign institutions and to elaborate on new principles of social justice. First, from outside, international competition is challenging the redistributive scope and de-commodifying power of the national welfare state. Many academic observers believe that the increase in cross-border competition in the markets for money, goods, and 
services has substantially reduced the maneuverability of national welfare states (Scharpf/Schmidt, 2000). Economic internationalization constrains countercyclical macroeconomic management, while increased openness exposes generous welfare states to trade competition and permits capital to move to the lowest-cost producer countries. Second, from within, ageing populations, declining birth rates, changing gender roles in households due to the mass entry of women into the labor market, the shift from an industrial to a service economy, and new technologies in the organization of work present new challenges. According to Gøsta Esping-Andersen (1999), the most important reason why the existing systems of social care have become overstretched stems from the weakening of labor markets and traditional family units as the default providers of welfare. Third, while policy makers must find new ways to manage the adverse consequences of economic internationalization and post-industrial differentiation, their endeavor to recast the welfare state is severely constrained, from the past, by long-standing social policy commitments in the areas of unemployment and pensions. In a period of permanent austerity and lower economic growth, the maturation of welfare commitments, ( the policies put in place to cater to the social risks associated with the post-war industrial era) now seem to crowd out the available space for new social policy initiatives, especially in social services (Pierson, 2001). Finally, as an intervening variable in the process, issues of work and welfare have become ever more intertwined with processes of European political and economic integration since the 1980s. It is fair to say that in the EU we have entered an era of semi-sovereign welfare states (Leibfried and Pierson, 2000). European economic integration has fundamentally recast the boundaries of national systems of employment regulation and social protection, both by constraining the autonomy for domestic policy options but also by opening opportunities for EU-led social and employment coordination and agenda setting (Ferrera, 2005; Zeitlin, 2005).

\section{WELFARE REGIMES AND EMPLOYMENT PERFORMANCE}

Employment is the most important measure for judging the sustainability of the welfare state and the success of social and economic policy. The reason for this is simple: benefits and social services have to be paid by the taxes and social security contributions from those in work. The more working people there are, the broader this funding base is. In the event of long-term unemployment, incapacity to work and early retirement, spending on social security goes up while at the same time revenues fall. From a sociological perspective, having a job also benefits people by giving them enhanced opportunities for self-actualization and 
self-esteem. Participating in the labor market is today the most important form of social interaction and, as such, is an indispensable element in achieving social cohesion.

Employment performance is conditioned not only by the economic and social policy challenges facing each welfare state, but more critically by variations in substantive policy design and institutional capabilities, including systems of political decision-making and interest mediation (Scharpf and Schmidt, 2000; Ferrera, Hemerijck and Rhodes, 2000). Hence, it would be a mistake to over-generalize the nature of welfare state change and to overlook these national distinctions and diverse trajectories. If Europe does have models, they are definitely plural rather than singular (Alber, 2006; Hemerijck, Keune and Rhodes, 2006). There is a rich literature on 'worlds' or 'families' of welfare which dates back to the 1980s and shows how key variables are systematically related to one another, producing distinctive clusters of nations in four 'social Europes' - Scandinavian, Conservative Continental, Southern European and 'Anglo-Irish' (Esping-Andersen 1990; Ferrera, Hemerijck and Rhodes 2000).

While the Continental welfare states rely on relatively high income replacement benefits, linked to the claimant's employment history and family situation, the Nordic welfare states not only offer generous income guarantees, but also a wide range of public social services and an active labour market policy aimed at maximising employment for both men and women. The Anglo-Saxon welfare states rely on relatively modest individualized incomedependent unemployment, sickness and old age benefit, with strict rules to social assistance. In the Mediterranean welfare states the family makes up for the underdevelopment of formal social assistance and services, while social insurance transfers cover core workers, especially in the area of pensions.

The eight new Central and Eastern European member states (NMS), which joined the EU in May 2004, occupy a special place. They have gone through two radical changes in the past 65 years - the shift from capitalism to state-socialism in the 1940s and from state-socialism back to capitalism after 1989. Before World War II, CEE welfare provisions mainly had a Bismarckian character, i.e. welfare arrangements were linked to and based on employment and occupation. The state-socialist era saw a universalization of the employment-based welfare system through full (and largely obligatory) employment. The state-socialist welfare state (Kornai, 1992) suffered from low quality services, queues, underemployment, limited choice and a generally low standard of living, even if it was also able to abolish deep poverty, create more equality, offer universal and free health and education services, and facilitate female employment by providing childcare, extended maternity leave and child benefits. 
After 1989, radically new ideas emerged concerning solidarity, equality and redistribution and the role and responsibilities of the state, market and individual. Profound welfare state reforms were the result. It is difficult to place the NMS welfare state in a particular group. By and large they are minimal welfare states: the percentage of GDP dedicated to social expenditure is low compared to the rest of the EU. Cumulative reforms since 1989, however, have made these systems more 'hybrid' rather than coherent regimes. While social benefits seem to be focused more and more on income replacement and linked to individual labor market histories in a Continental 'Bismarckian' style, health care, family policy and social assistance display important universalistic as well as 'Anglo' market-based trends (Keune, 2006).

With respect to employment, there has been a significant increase in virtually all mature European welfare states over the last decade whereas the new member states experienced a transformation crisis. Figure 1 shows the employment/population ratios among people in the working age population. What is striking is, first, the long-term increase in employment in most countries and, second, some persistent differences in the overall share of people in gainful employment across countries and families of welfare states.

\section{Figure 1: Employment/population ratios 1997 and 2006}

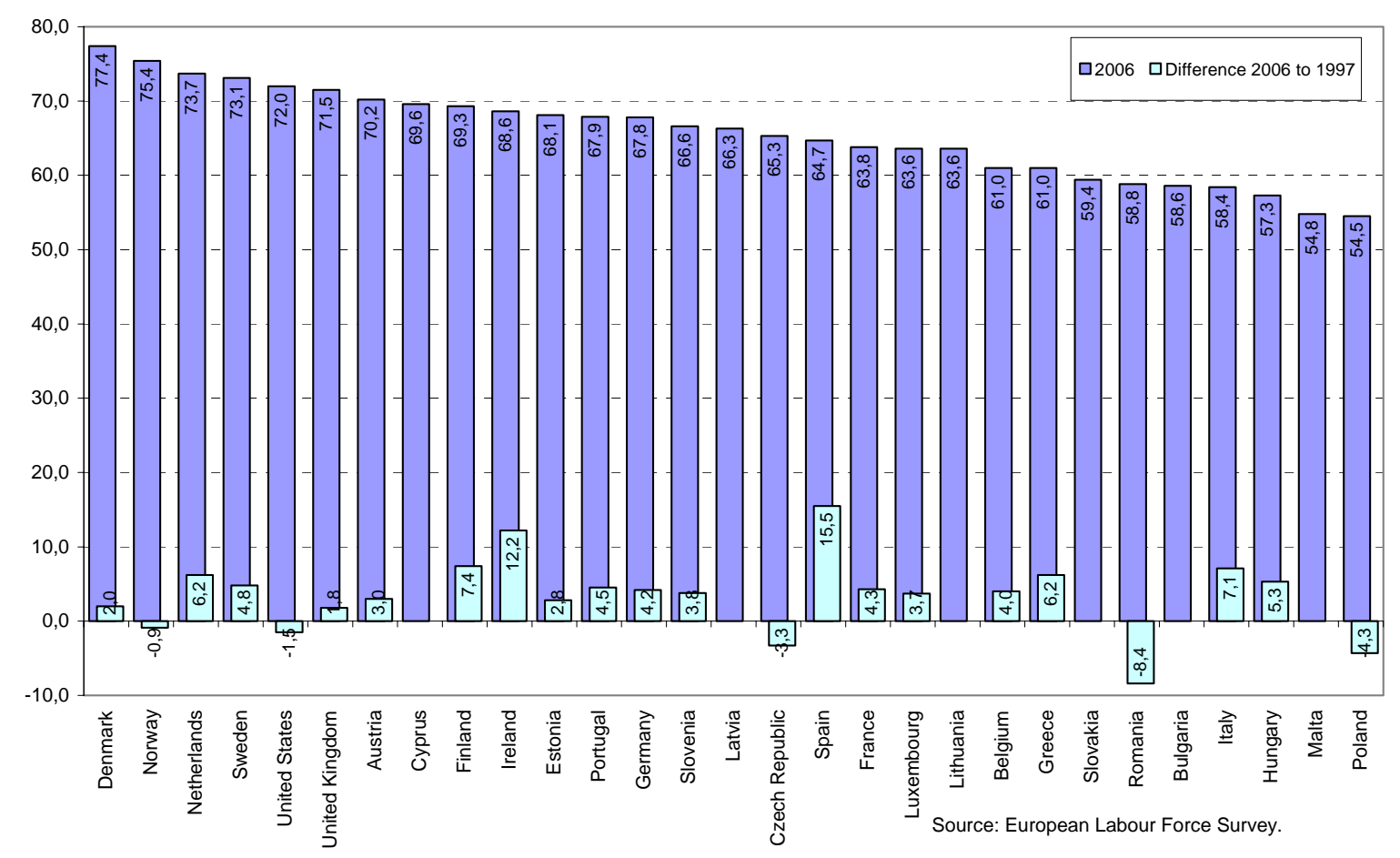

Figure 2 shows the long-term development of employment rates for selected European countries and the US. Unfortunately, there are no similar time series for the new member 
states. The convergence over time within the EU is striking. Now, both the Anglo-Saxon and the Scandinavian countries have about 75 to 80 percent of the working-age population in employment. The same level is also achieved by the Netherlands after an impressive increase in employment over the last two decades. The other Continental and Southern European countries are still behind with employment rates of 60 to 70 percent. But even there we can see some progress, in particular in Spain and Italy while France and Germany have been more stagnant.

Figure 2: Employment/population ratios, 1980 - 2006

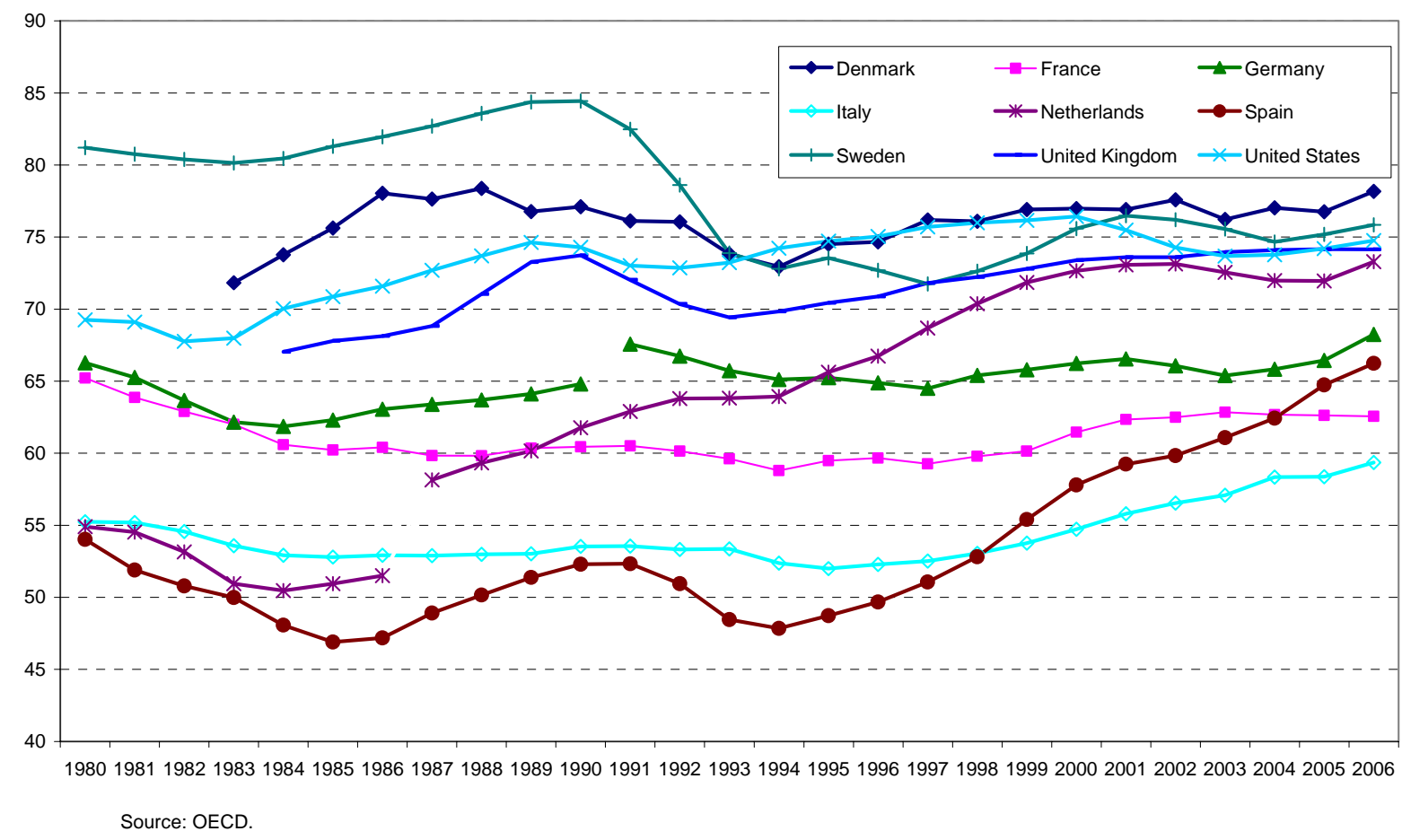

Mirroring the improvement in employment performance, standardized unemployment rates declined in most European countries over the last decade as figure 3 shows. What is most remarkable is the strong decline in unemployment in some Southern and Continental European countries such as Spain, France, Italy as well as in Sweden and Finland which could overcome the deep crisis of the nineties. Even the low-unemployment countries Denmark and the Netherlands achieved further progress so that there is now virtually full employment with lower unemployment and higher employment rates than in the US, even though, as the chapter by Saraceno (in this volume) shows, the incidence of long-term unemployment is still high. 


\section{Figure 3: Standardized unemployment rates}

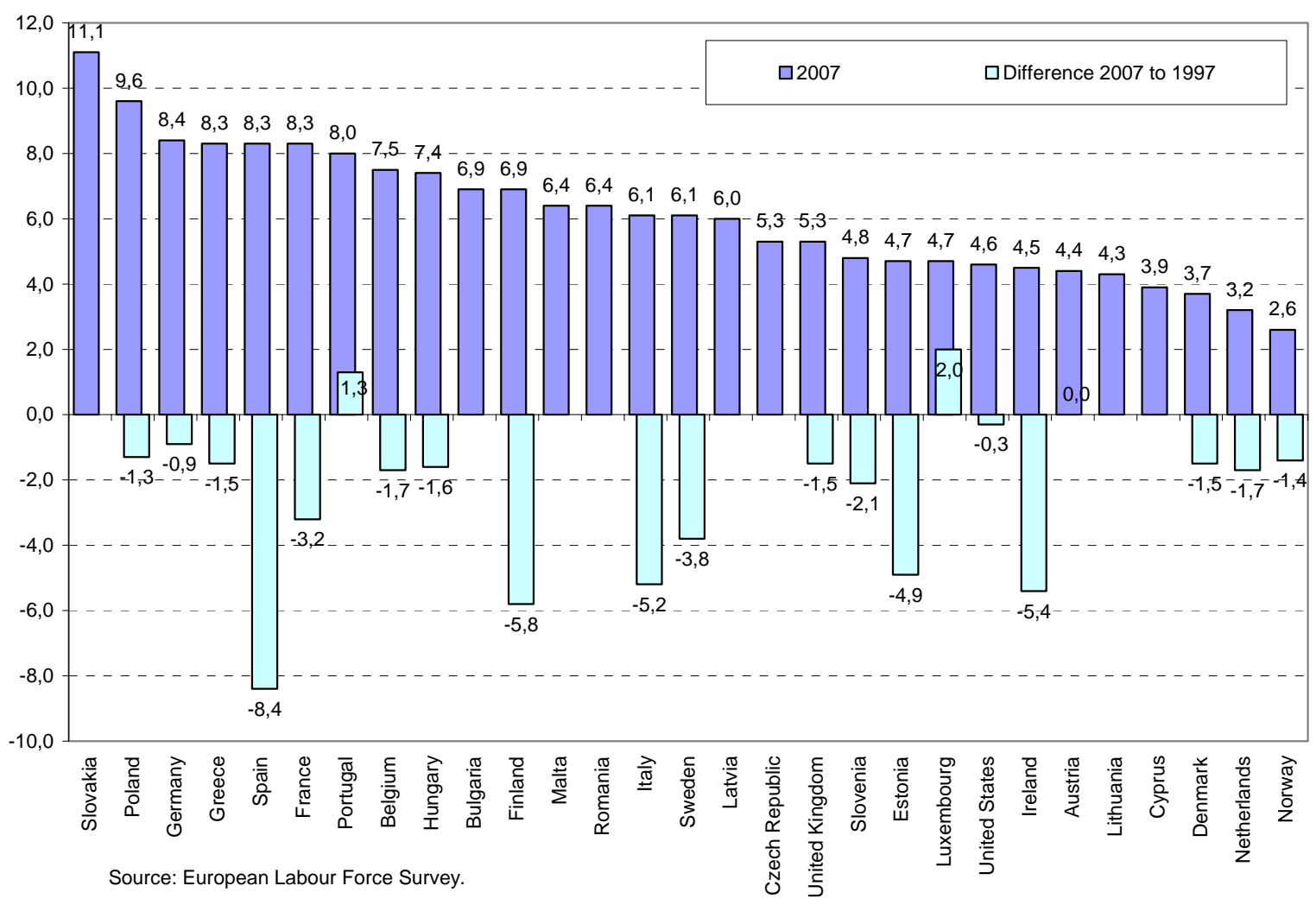

High employment is not only found in market-oriented arrangements. The government plays an important role in the Scandinavian welfare state model as an employer in the laborintensive social services sector. As a result, the Scandinavian welfare states create wide opportunities for men and women with lower education levels to work in the public sector, as well as creating employment for highly-trained professionals. About a quarter of the labor force in Denmark and Sweden (mainly women) are employed in the public services sector. The expansion of the number of jobs in social services, childcare, and care for the elderly from the 1970s onwards gave rise to a self-reinforcing mechanism: more women entered the labor market, leading to a marked reduction in the amount of care provided within (working) families, which in turn led to an increase in demand for professional care services.

The response of the Continental and Mediterranean welfare states to the process of economic restructuring in the 1970s and 80s was aimed at keeping open unemployment low by limiting labor supply with the help of a host of early retirement options. Growing demands on social security led to burgeoning costs to be borne by the labor market. From the middle of the 1980s onwards, employers in Continental welfare states increasingly began using laborsaving technology and shedding less productive employees via the social security system. This turned the Continental productivity squeeze into an inactivity trap. A vicious cycle arose 
of high gross wage costs, low net wages, the exit of less productive workers and rising social costs, creating a spiral of falling employment and rising economic inactivity. This also undermined the financial basis of the social security system. It was not until the second half of the 1990s that there was a limited increase in the employment rate in the Mediterranean welfare states, which, in fact, have seen some of the biggest employment gains in the EU over the last decade. The Netherlands occupies a special place comparatively, because it was the first Continental welfare state with a historically low female employment rate to improve its performance, trending towards Scandinavian levels.

In the (prime age) age group aged 25-54 years, a strong convergence can be observed since the middle of the 1990s (figure 4). Over the last decade we can observe substantial recovery in the Scandinavian countries after the crisis in the early 1990s, but also considerable improvement in the Continental and Southern European countries. The Anglo-Saxon welfare states also showed a trend of upward consolidation so that most welfare states now have prime age employment rates of 75 to 85 per cent except for some of the Central and Eastern countries.

\section{Figure 4: Prime age employment rate (25-54), 1997 and 2006}

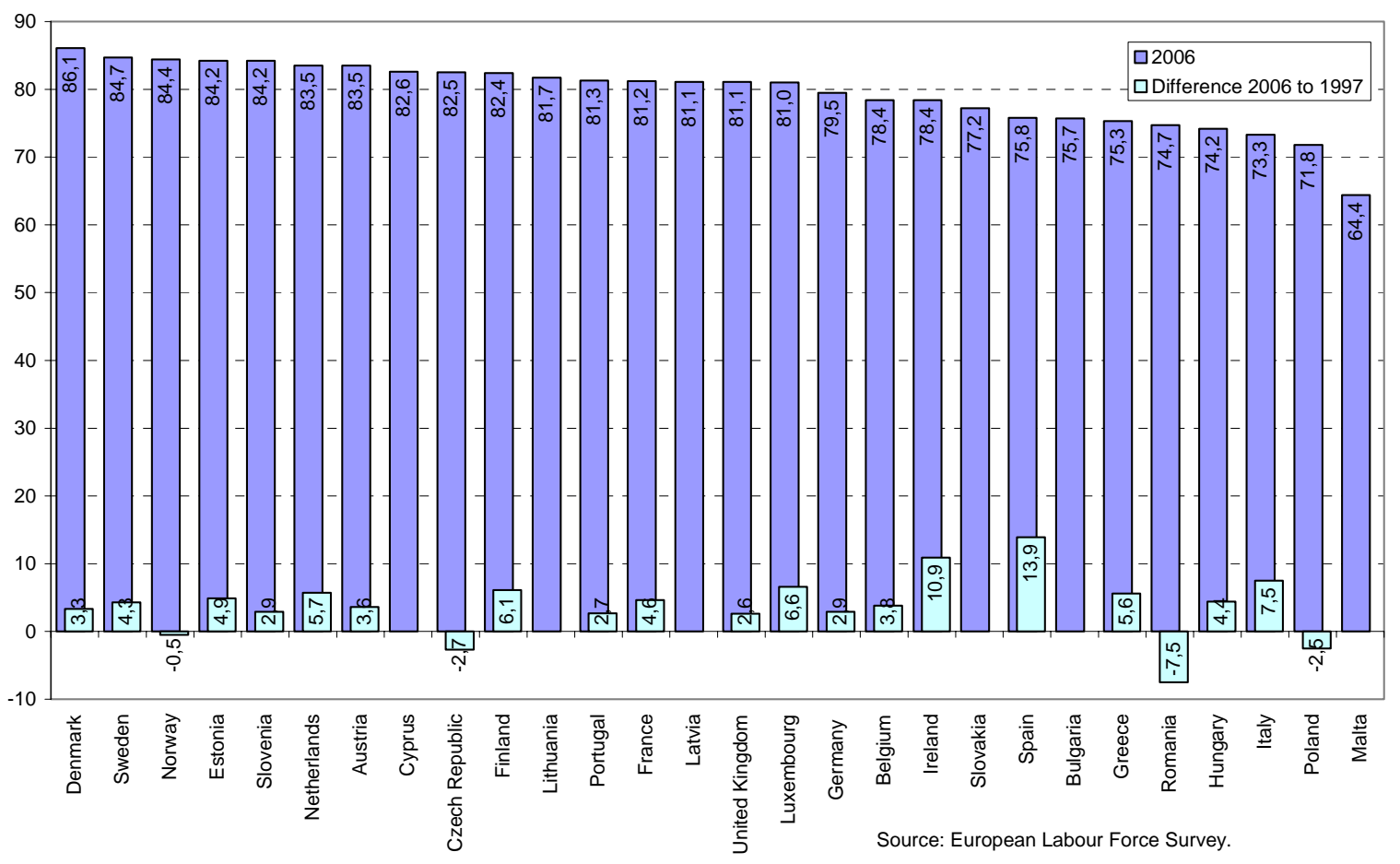

There is much more regime-specific variation regarding the employment rates of older workers, women and the low-skilled. Differences in the extent to which these three groups are integrated into the labor market basically determine differences in the overall 
employment rate. With respect to the 55-64 age cohort (see figure 5), Belgium has the lowest employment rate of the EU-15 (32 percent) while Sweden has the highest (almost 70 percent). In the EU-27 Poland and Malta still have particular problems regarding the labor market position of older cohorts. The Continental and Mediterranean welfare states and most of the new EU member states saw a dramatic fall of more than 30 percent in the employment rate of older workers from the 1980s due to early retirement, particularly among men. Since the end of the 1990s, the employment rate among older workers has been increasing strongly in Finland, but also in some Continental welfare states, with the Netherlands taking the lead.

\section{Figure 5: Employment rates of older workers (55-64), 1997 and 2006}

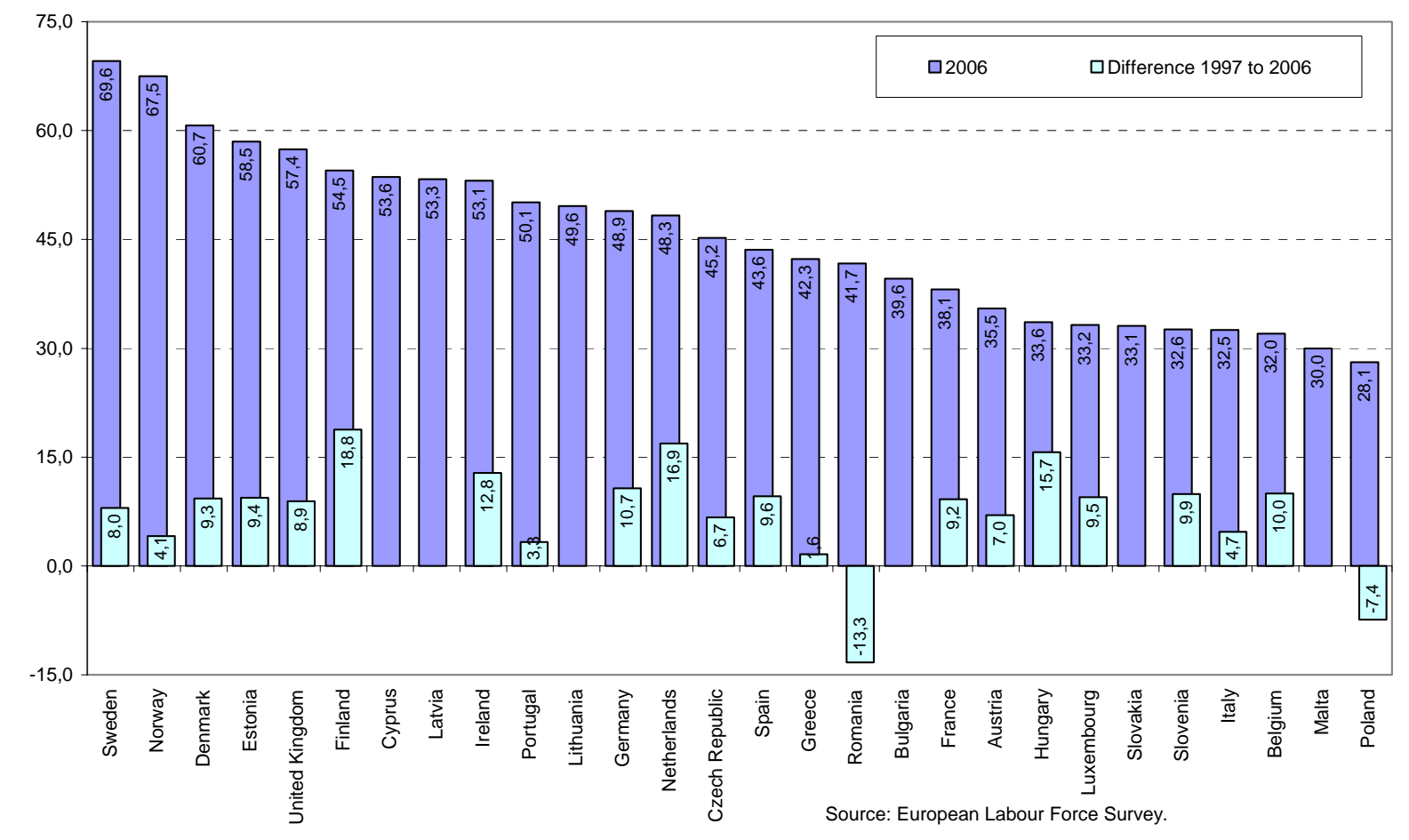

Looking at gender, we see some cross-country convergence in the employment rate of men between 70 and 80 percent. Male employment declined slightly in Denmark and Norway, but grew in most other EU-15 countries. Again, there is a structural gap in male employment in most CEE countries compared to the EU-15. 
Figure 6: Employment rate of men, 1997 and 2006

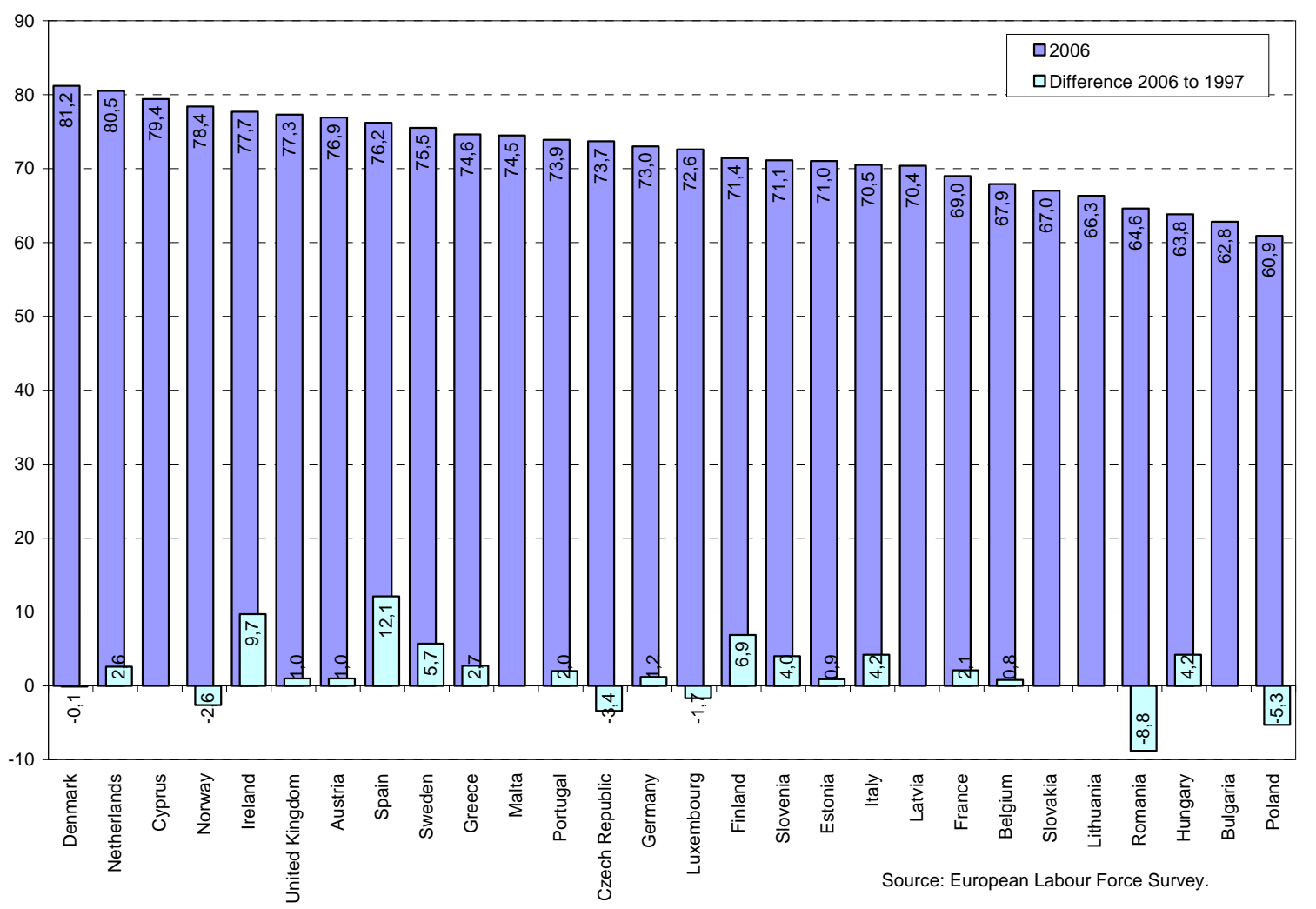

The labor market entry of women is the most striking recent development in European welfare states (see figure 7). In the early 1970s, the Netherlands had the lowest female employment rate in the OECD, at 29.2 percent. This was lower than the figure in Ireland, Greece, Spain, and Italy, where the rate was just above 30 percent. Since then the employment rate of women has grown strongly. In net terms, the rate in the Netherlands has increased to 67 percent, the sharpest rise of any OECD member state. The female employment rate in the Netherlands is currently still lower than in the Scandinavian welfare states, but here as elsewhere younger cohorts are undergoing a notable convergence in the direction of stronger labor force participation. 


\section{Figure 7: Female employment and share of women's part-time work, 2006}

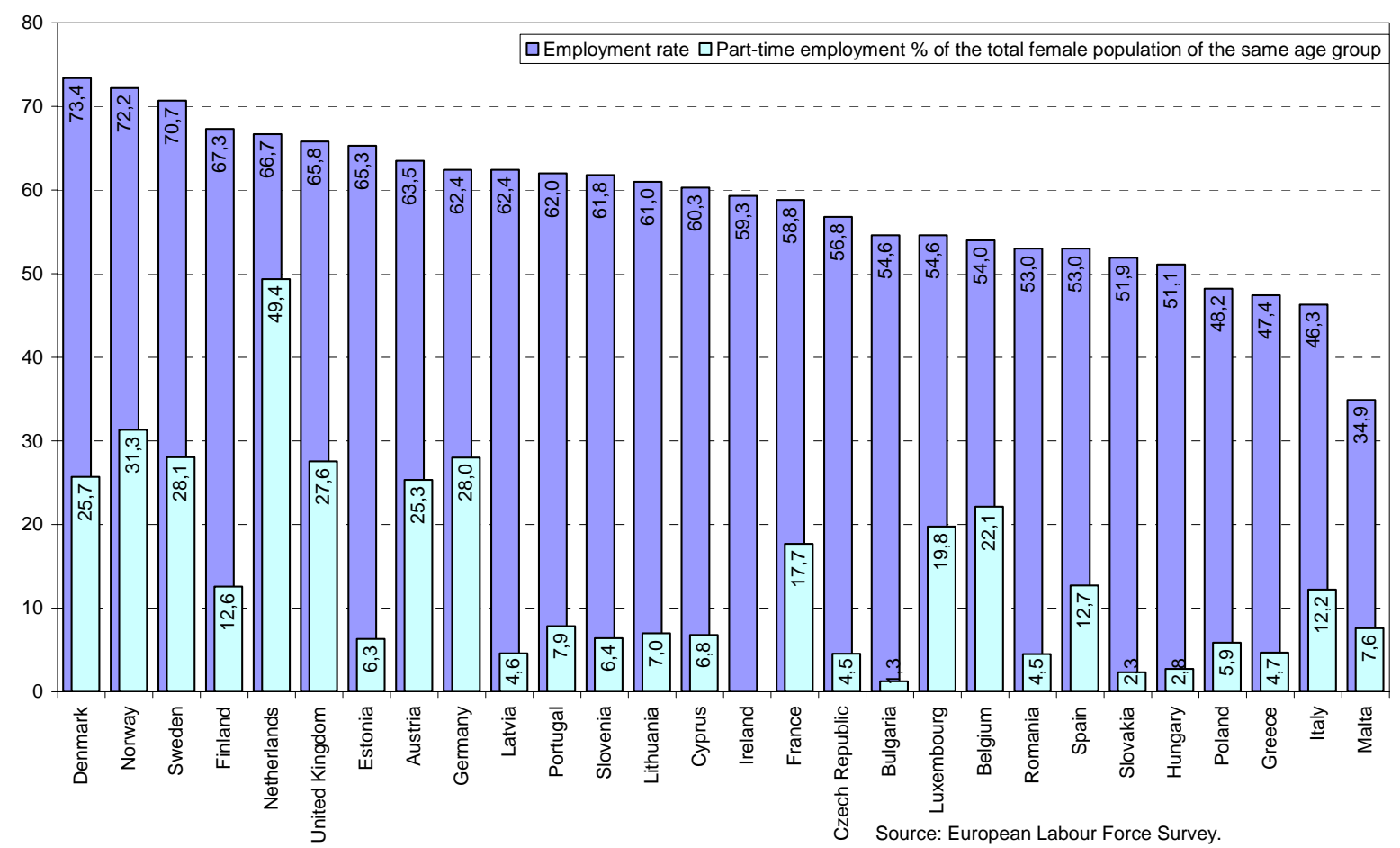

The low - and only marginally increasing - employment rate among women in the Mediterranean welfare states, in particular, points to a number of key barriers on the Southern European labor market. In the Continental and Anglo-Saxon welfare states, the ability to work part-time has created an important means of entry to the labor market for women, in particular in the Netherlands. In countries with a long-standing tradition of female employment, such as the Scandinavian countries, part-time employment is less common. For younger cohorts, female employment in Southern and Continental Europe is rapidly catching up to Northern European averages.

Employment rates by skill levels differ mostly for the labor force with less than upper secondary schooling or vocational training, less so for the high skilled. Figure 8 shows marked differences in low skill employment across countries and families of welfare states. Particular deficits are found in the CEE countries, but also in some Continental European countries such as Belgium, Italy or Germany where only about half of the low-skilled are integrated into the labor market. Given the strong pressures of technological progress and globalization it is interesting to see that there is no general decline in the employment rates of the low skilled. 


\section{Figure 8: Employment rates of the low skilled, 1997 and 2006}

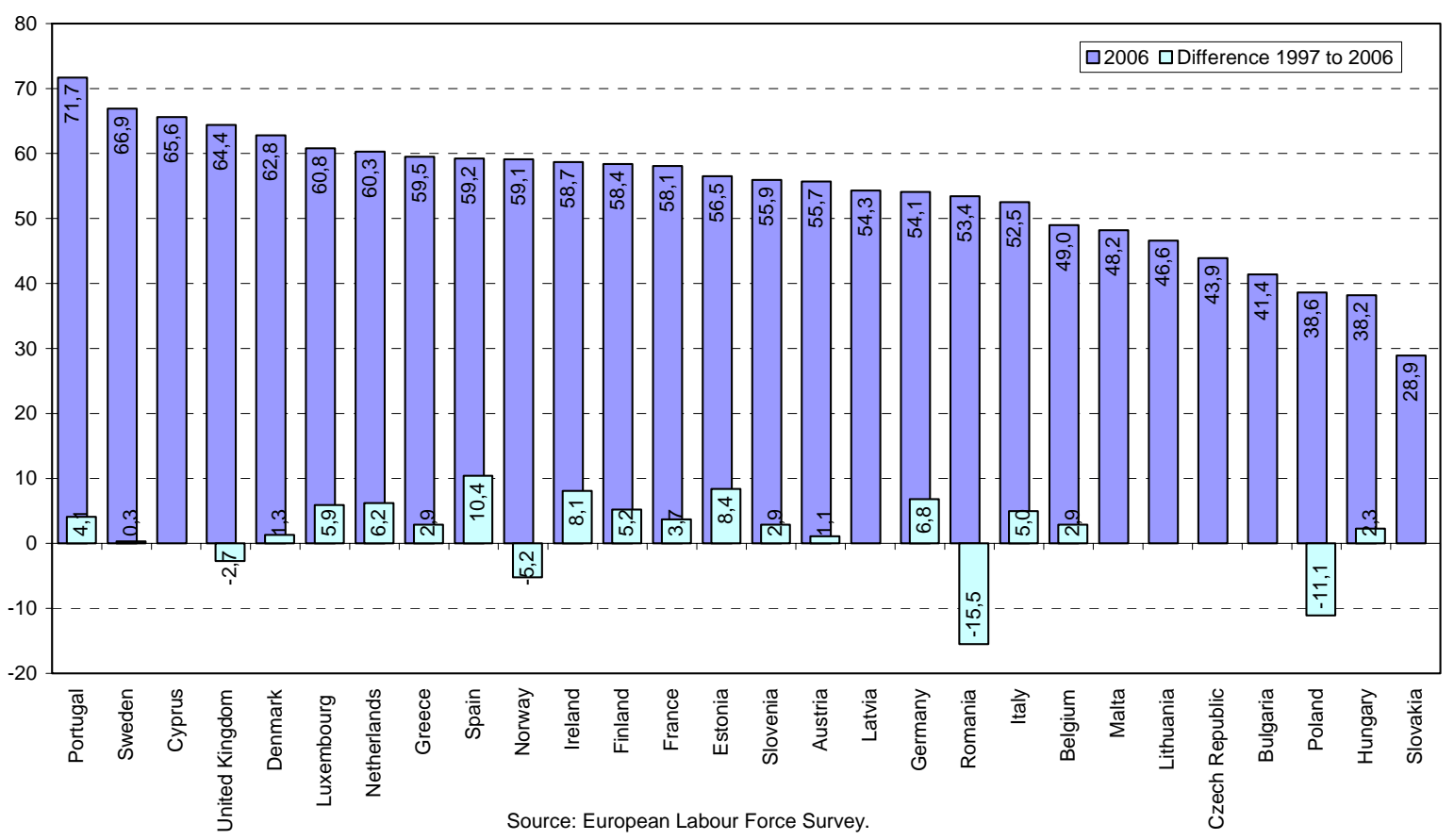

Today the highly skilled groups surpass, by about 15 percentage points, the Lisbon benchmark of 70 percent participation in gainful employment, independently of welfare regime characteristics. Hence, there is considerable convergence of employment at a high level.

Regarding the role of the state, there are core policy areas with direct impact on the labor market, in particular (a) regulatory policies such as employment protection or statutory minimum wages and (b) the provision of monetary benefits and services. Regarding the latter element of government activity, we can basically differentiate between social spending for benefits and expenditure for services, especially active labor market policies, public childcare and education. Despite changes in the overall economic environment and sequences of policy reforms, expenditure levels on social protection expressed as a percentage of GDP have remained relatively stable or even increased over the last two decades (see also the chapters by Castles and Gilbert in this volume).

Turning to services, the variation across countries and families of welfare states is more pronounced. The provision of public child care and pre-schooling shows marked differences across countries, with the Scandinavian countries, Belgium and France offering the best infrastructure, and most Continental, the Mediterranean and the Central European countries 
lagging behind (Table 2, OECD 2007b). This is major factor driving or restricting female employment.

Table 2: Child care and pre-school enrolment, ca. 2004

\begin{tabular}{|c|c|c|c|c|c|}
\hline & \multicolumn{4}{|c|}{$\begin{array}{l}\text { Enrolment in daycare for the under } 3 \mathrm{~s} \text { and pre-school from } \\
\qquad 3 \text { to } 6 \text { years }(\%)\end{array}$} & \multirow{2}{*}{$\begin{array}{c}\begin{array}{c}\text { Expected years } \\
\text { in education } \\
\text { for } 3 \text { to } 5 \text { year } \\
\text { olds }\end{array} \\
3 \text { to } 5 \text { years } \\
\end{array}$} \\
\hline & Under 3 years & 3 years & 4 years & 5 years & \\
\hline Denmark & 61,7 & 81,8 & 93,4 & 93,9 & 2,7 \\
\hline Norway & 43,7 & 79,4 & 86,9 & 89,0 & 2,6 \\
\hline Sweden & 39,5 & 82,5 & 87,7 & 89,7 & 2,6 \\
\hline Belgium & 38,5 & 99,3 & 99,9 & 99,7 & 3,1 \\
\hline Netherlands & 29,5 & 32,3 & 74,0 & 98,4 & 1,7 \\
\hline United States & 29,5 & 41,8 & 64,1 & 77,0 & 1,8 \\
\hline France & 26,0 & 100,0 & 100,0 & 100,0 & 3,2 \\
\hline United Kingdom & 25,8 & 50,2 & 92,0 & 98,2 & 2,4 \\
\hline Portugal & 23,5 & 63,9 & 79,9 & 90,2 & 2,3 \\
\hline Finland & 22,4 & 37,7 & 46,1 & 54,6 & 1,4 \\
\hline Spain & 20,7 & 95,9 & 100,0 & 100,0 & 3,1 \\
\hline Slovak Republic & 17,7 & 60,3 & 71,7 & 84,7 & 2,2 \\
\hline Ireland & 15,0 & 48,0 & 46,6 & 100,0 & 1,5 \\
\hline Germany & 9,0 & 69,5 & 84,3 & 86,7 & 2,4 \\
\hline Hungary & 6,9 & 71,0 & 92,3 & 97,8 & 2,6 \\
\hline Greece & 7,0 & .. & 57,2 & 84,1 & 1,4 \\
\hline Italy & 6,3 & 98,7 & 100,0 & 100,0 & 3,0 \\
\hline Austria & 4,1 & 45,9 & 82,1 & 93,1 & 2,2 \\
\hline Poland & 2,0 & 26,1 & 35,7 & 46,2 & 1,1 \\
\hline Czech Republic & 3,0 & 68,0 & 91,2 & 96,7 & 2,6 \\
\hline
\end{tabular}

Source: OECD Family Database.

Public child care provision is no longer seen merely as a facilitator of female employment or as a means to reconcile family and work. It is increasingly perceived as the first pillar of lifelong learning. As investments at early stages of the lifecycle provide the basis for further success in education and training, they are seen as an effective and efficient tool to ensure skills acquisition also at later stages of general education or vocational training (see also Allmendinger in this volume). As a consequence, there are also marked differences in terms of participation and intensity of lifelong learning activities (OECD, 2005). In general, participation in continuous education and training is more pronounced in the Scandinavian countries and the United Kingdom where on-the-job training is also a functional equivalent to more formal vocational training. However, despite some increases in most countries, the adjustment of skills over the lifecycle is still far from perfect. Particular deficits are found in the Continental and Southern European countries as well as in most NMS. 


\section{Figure 9: Participation in lifelong learning, 1997 and 2006}

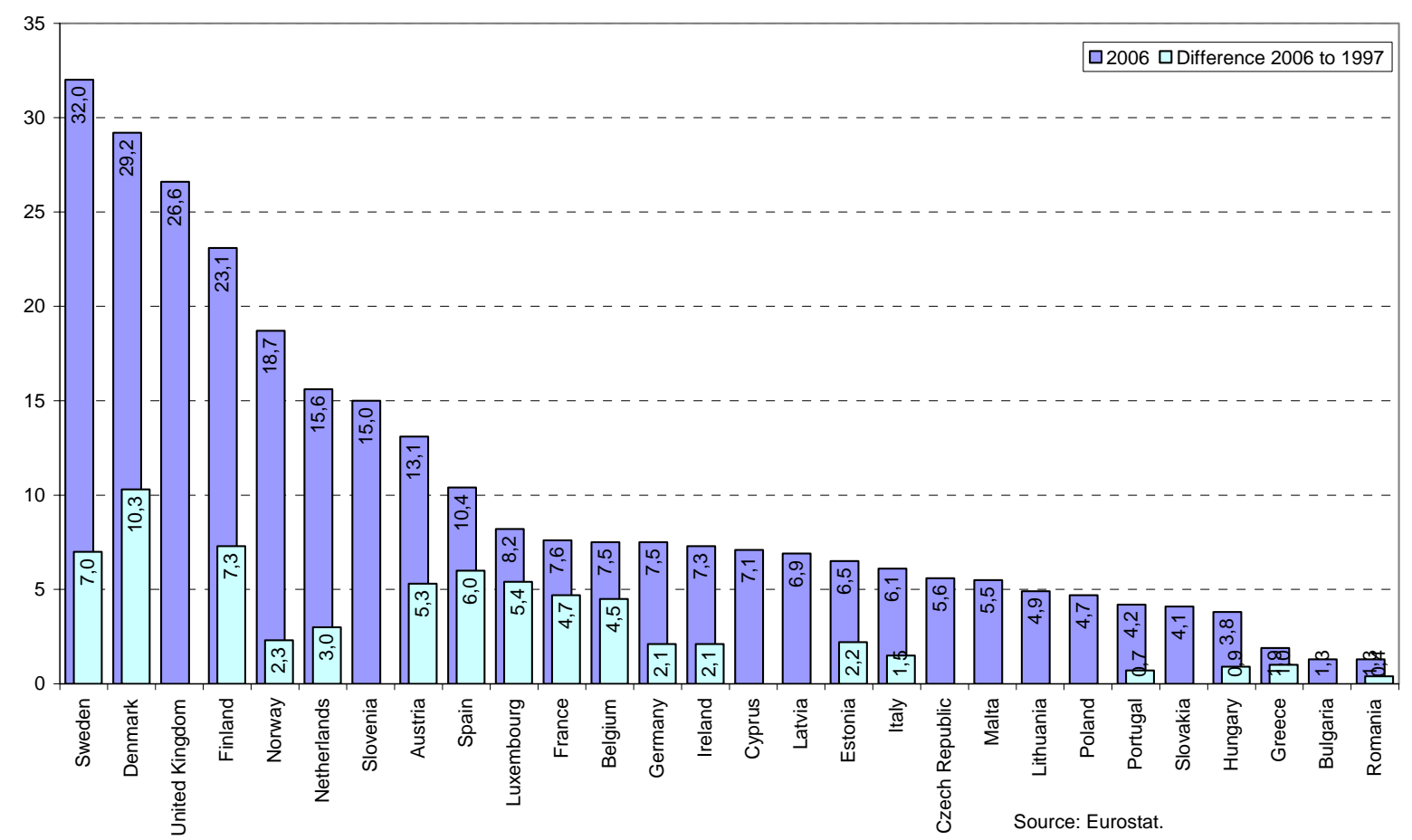

The differences in the allocation of public resources to either investment policies (such as education and training) or to compensating policies such as social benefits and passive and active labor market policies are most evident in figure 10 which shows how public spending on education and social expenditure in per cent of GPD combined in 2004. While the over-all association between both areas of public spending is positive, some countries, in particular the Scandinavian ones, as well as Belgium and France, combine above-average spending on social policies with above-average spending on education. Germany and Italy, in contrast, spend a lot on social purposes but are relatively stingy on educational expenditure. Many new EU member states devote few resources to social policies, but some achieve the European average in terms of educational spending such as Poland, Hungary and the Baltic states. 
Figure 10: Public social expenditure and spending on education in per cent of GDP, 2004

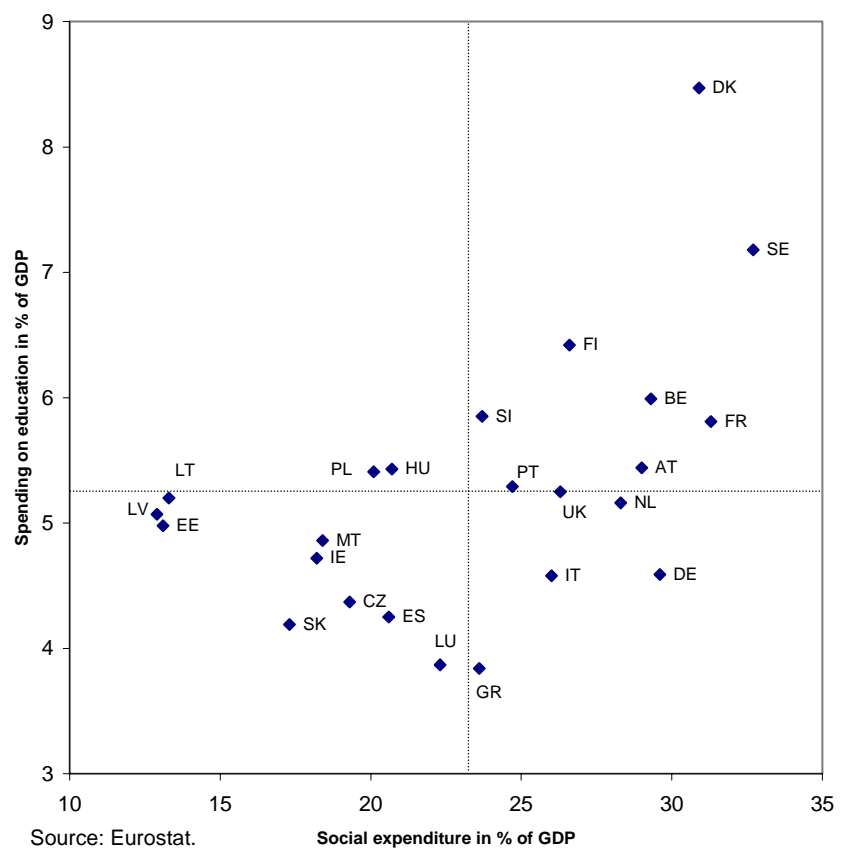

Data on the earnings dispersion of full-time workers and the incidence of low pay, i.e. earning lower than two thirds of the median, show a proliferation of inequality in most countries (Table 3). Yet there are marked differences between country clusters. Some CEE countries such as Hungary and Poland and the Anglo-Saxon labor markets have a large wage dispersion, while the Scandinavian countries continue to have relatively egalitarian wage structures. 
Table 3: Earnings dispersion and incidence of low pay

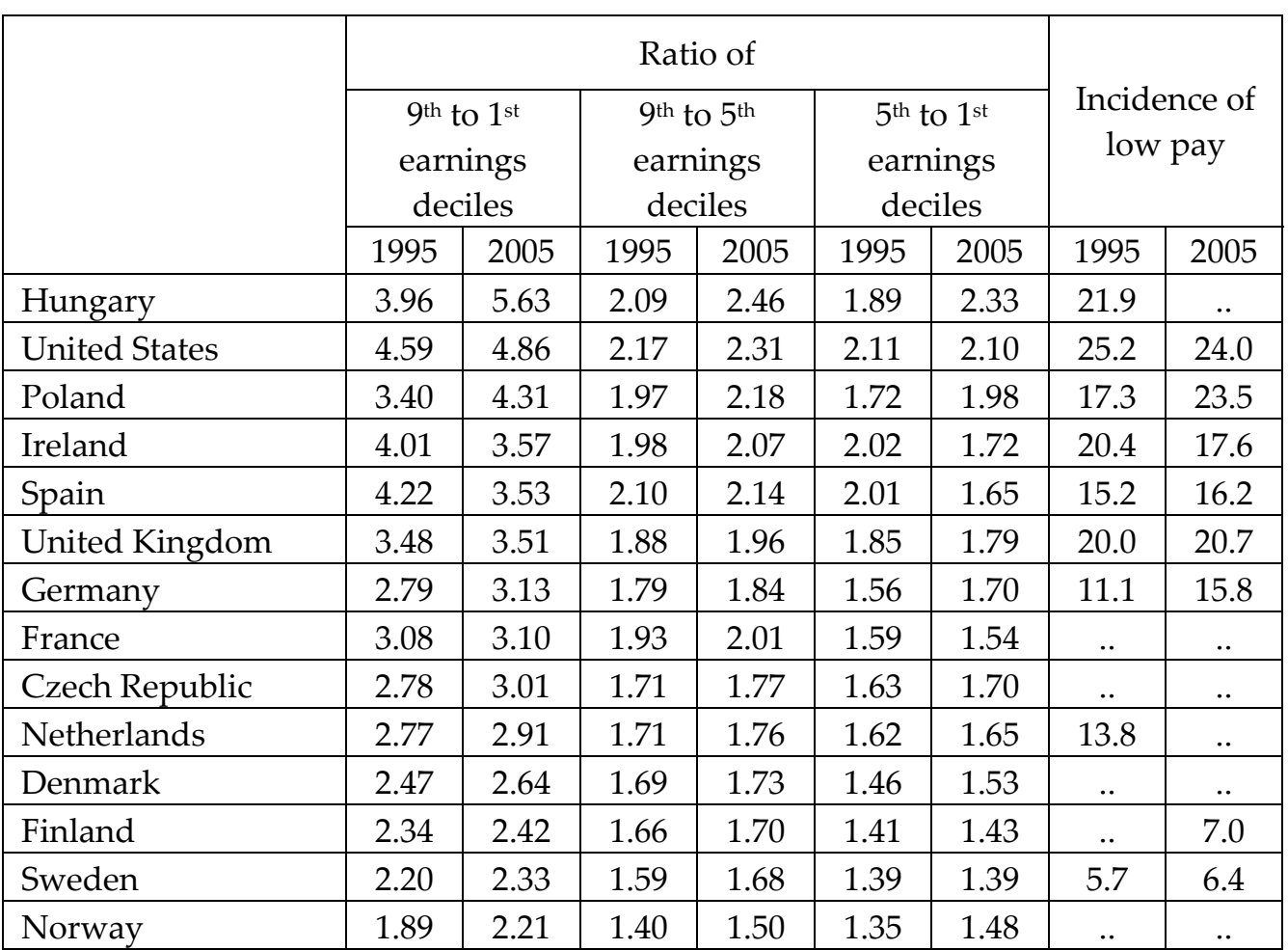

Source: OECD 2007a.

Summarizing the data presented on employment performance, we can see, first and foremost, an overall improvement in employment and a significant decline in unemployment across most European welfare systems over the last ten years.

- The average employment rate of the EU-15 countries increased considerably from $61 \%$ in 1997 to $66 \%$, the EU-27 moved from $61 \%$ to $65 \%$.

- The employment rate for women rose from 52\% to 59\% in the EU- 15 (57\% for the EU27), bringing it within reach of the Lisbon objective of $60 \%$ in 2010.

- For older workers, aged 55-64, the employment rate has risen from $36 \%$ to $45 \%$ in the EU-15 and to $44 \%$ in the EU-27. Here, the distance to the Lisbon target of $50 \%$ is a bit larger.

There is not only "contingent convergence" in performance - but also in terms of policies as we will show below. As there are still structural and long-lasting differences between different national welfare states or families of welfare states, it would certainly be wrong to say that Europe as a whole suffers from severe employment deficits - this is only true for some countries, but not for others.

The overall picture across the European countries shows that quite different economic and welfare state models can achieve high and probably sustainable employment levels. This 
suggests that there is no necessary trade-off between employment performance and the size of the welfare state, that a large public sector does not necessarily hurt employment mobility and competitiveness, that there can be a positive relationship between fertility and high levels of female employment and that labor market flexibility and low poverty more often than not go together with high levels of employment. Hence, high employment is not necessarily associated with higher inequality (see also Ferrera et al, 2000; Esping-Andersen et al, 2002; Lindert, 2004; Kenworthy, 2004; Aiginger and Guger, 2006; OECD, 2006a).

\section{REGIME SPECIFIC REFORM AGENDAS}

The overall improvement in employment performance is related to groundbreaking social policy changes which were enacted in the majority of European welfare states. Since the late 1970s, consecutive changes in the world economy, European politics (most spectacularly the demise of communism in Eastern Europe), labor markets, and family structures, have disturbed the once sovereign and stable social and economic policy repertoires. As a consequence, all developed welfare states of the European Union have been recasting the basic policy mix upon which their national systems of social protection were built after 1945 . Below we render a stylized sketch of the reform agendas since the 1990s across the different regimes so as to bring out both the similarities and differences within regime clusters.

Nordic 'dual-earner' post-industrialism

Thanks to their overall institutional coherence, together with their strong full employment and active labour market policy legacy, the Nordic welfare systems have proven to be relatively well equipped for the challenges of economic internationalization, aging societies, gender equality, and transition to the post-industrial economy. In response to the oil shocks of the 1970s and 1980s, the Nordic countries expanded employment by increasing public sector employment. The lasting effect of the expansion of public services to families, together with the rise in female labour supply, has been a high level of employment for both men and women, with women working largely in public social services, like education, child care and elderly care. This policy of 'de-familialization' of caring responsibilities subsequently catalyzed the dual-earner norm throughout the Nordic countries (Kuhnle, 2000).

This is not to say, that economic internationalization has not generated problems of costs competitiveness. The Swedish public employment growth strategy, based on fiscal demand stimulus and monetary devaluation in the 1980s, led to a severe macroeconomic imbalance in the early 1990s. Throughout the 1990s, Nordic countries grappled with pressures to contain high and increasing costs and to reorganize labor markets so as to generate more demand for private employment. Sweden and Denmark have begun to reduce public-sector 
employment but the tradition of universalism remains largely unquestioned even if cuts in replacement rates (e.g., sickness benefits) or basic guarantees (e.g., family allowances) have occurred. Eligibility for cash benefits, especially duration, has been tightened in Sweden and Finland. A core dimension in the Nordic reform agenda consisted of 'activation', i.e., the modification of programs to encourage actual and potential beneficiaries to find and maintain gainful employment. Denmark has gone furthest in changing the institutional profile and logic of labour market policies. Denmark has deployed a wide array of 'activating' instruments including information and counseling, subsidized employment in public and private sectors, training and educational initiatives, and job rotation combined with a (temporary) expansion of leave possibilities for employed workers (Andersen and Svarer, 2007). The Danish model of 'flexicurity' adheres to the principles of a 'golden triangle' of a flexible labour market, generous social protection, and an active labour market policy (Erhel and Gazier, 2007). The Nordic countries, and especially Finland, have pursued a deliberate human capital response, so as to secure a productive workforce, to the challenges of economic internationalization and post-industrial social change. The Finnish success can be traced back to a public education system which provides highly skilled people and a culture of innovation. Co-ordinating public and private efforts, the Finnish government has deliberately invested in research and development. The idea that sustaining the welfare of an aging population requires a highly productive labor force is much more widespread in Scandinavia than in any of the other welfare clusters. Cognitive inequalities are substantially lower in Scandinavia and the diminishing impact of social origin on educational performance coincides with the expansion of universal day care. Important pension reforms have also been undertaken to strengthen the links between contributions and benefits in Sweden and Finland. In order to keep older workers in the workforce, Finland has developed policy approaches to improve the occupational health, work ability and well-being of ageing workers.

The Scandinavian tradition of universal coverage provided an effective safeguard against poverty and exclusion, spells out of work and broken or changing career trajectories, with low transaction costs. Moreover, the incentive structure of nationwide social insurance and active labour market implied portability, which promotes labour mobility, while avoiding poverty traps. A wide array of services has allowed the Nordic welfare state to respond more effectively to the needs of dual earner families and to socialize the costs of care for children. As a consequence, high rates of labour market participation for both men and women and older workers have reduced the financial strains on pension systems. Spurred by the recession in the early 1990s, most reforms were based on a strong consensus among the social democratic governments and bourgeois parties as well as employers and trade unions 
which all agreed on the need for modernization (Schludi, 2005). The Nordic experience clearly shows that (high) expenditure levels are not the critical factor for effective policy responses to new challenges, but that system design and reform approaches are what really matter.

Reversing the Continental syndrome of 'welfare without work' From the 1970s onwards, most Continental welfare states began using disability pensions, early retirement, and long-term unemployment schemes to remove older and less productive workers from the labor market. Both center-left and right government preferred increasing social contributions over cutting social benefits. Luring people out of the labor market by facilitating early retirement, increasing benefits for the long-term unemployed, lifting the obligation of job search for older workers, discouraging mothers from job search, favoring long periods of leave, easing the access to disability pensions and reducing working hours, made up the characteristic of the Continental welfare without work policy strategy that became popular in the 1980s and for most of the 1990s. Backed by the unions and employers this strategy produced short-term gains, but eventually engendered a severe employment crisis in most Continental welfare states.

The continental employment problem is directly related to payroll-based social insurance financing and relatively strict labor market regulation. The strategy of boosting international competitiveness by early retirement and high-quality training and education may have placed a premium on high productivity, but its indirect effect was a substantial increase in the tax burden on labor, as ever fewer workers had to support ever more people outside the active labor market. Productivity growth thus led to a vicious cycle of rising wage costs and the exit of less productive workers requiring further productivity increases and eliciting another round of workforce reductions through subsidized early exit (Hemerijck and Manow, 2001). In addition, strict employment regulation, including minimum wages and hiring and firing restrictions, protected the insiders in key industries, while harming the participation of outsiders, youngsters, women, older workers, low skill groups and ethnic minorities. From the 1990s onwards the policy of labor supply reduction came to be brandished as a policy failure and, if continued uncorrected, as a threat to the survival of the Continental welfare state and the Rhineland model more generally. But the Continental syndrome of welfare without work proved extremely difficult to reverse.

The severe recession in the early 1990s following the German unification produced a sharp rise in unemployment and public debt, constraining the scope for further labor supply reduction. From the early 1990s on, high taxes and the EMU entrance exam served to shift 
policy attention to employment creation, generating a multidimensional reform agenda to curtail passive welfare and pension commitments, to improve family policy, reform labor markets and reduce social charges. The Dutch were the first who managed to escape the Continental employment crisis through a long-term strategy combining wage moderation, the activation of social insurance, active labor market policy, and more labor market flexibility, all developed largely in agreement and with the support of the social partners (Visser/Hemerijck, 1997). In contrast to the Dutch success at "activation", the Belgian social insurance scheme has been transformed from a traditional Bismarckian system into one with an overriding emphasis on minimum income protection and universal coverage. Over time, this has resulted in a de facto targeting of benefits on the basis of individual, household and family need. In France, minimum income protection has likewise shifted from payroll contributions to general taxation so as to reduce non-wage costs and encourage job creation. Germany has been much slower in embracing reform. Only the highly unpopular Hartz reforms pursued under the Social-Democratic/ Green coalition government since 2002 have sought to reduce benefit dependency and to activate the long-term unemployed into work via a combination of cuts in benefits, together with a shift towards a means-tested income support scheme for the long-term unemployed and more coherent activation measures (Eichhorst, Grienberger-Zingerle and Konle-Seidl, 2008, Clasen and Clegg 2006). Both France and Germany now have a repertoire of (a) less regulated work contracts such as fixedterm employment or temporary agency work and (b) areas with low social contributions or employer subsidies, e.g. low-wage jobs exempt from employers contributions and a multitude of "contrats aidés" in France and Minijobs and different subsidization schemes in Germany. In combination with further steps in favor of more jobs, time flexibility, including part-time work, or wage moderation for standard jobs in the core of the labor market, these reforms contributed to making Continental welfare states more employment-friendly.

Pension reform in Continental welfare states has been especially difficult, but not impossible to implement (Immergut, Anderson and Schulze, 2007). Pension contribution rates have risen in Germany and the Netherlands, while Austria extended the reference period as part of a larger package of reforms. Germany has moved from gross to net wage indexation and France has shifted from wage to price indexation. The Netherlands, France, and Belgium have started building reserve funds to sustain pension provision when the baby-boom generation retires (Esping-Andersen et al., 2002). Germany took first steps in establishing a multi-pillar system of pension provision, including a partial privatization of pensions with a greater emphasis on occupational pensions. The age-limit for retirement will gradually be raised to 67 years. France represented a critical case of policy blockage until Sarkozy's entry 
into office in 2007 due to an absence of consensus among mainstream parties and between unions and employers.

From the mid-1990s onwards, the new goal of reconciling work and family life gained prominence in Continental countries. While the Netherlands developed the 'combination scenario' of childcare through the workplace for mothers working part-time, the Schroeder governments in Germany visibly put child care at the core of an increasingly employment oriented policy. The Grand Coalition of CDU/CSU and the SPD expanded tax reimbursements to cover child care costs and introduced a new parental leave benefit, while expanding (public) child care facilities.

It is no exaggeration to say that the allegedly most change-resistant and veto-prone Continental welfare states have transformed the most over the past decade! Continental welfare states are in the midst of a general paradigmatic shift away from systems geared to income and status maintenance towards activating and employment friendly as well as gender neutral welfare systems. This suggests an element of policy convergence with the Nordic model. The method of financing saw shifts from contributions levied on earnings from work to more general taxation. In the governance structure we observe a weakening of the social partners in favor of privatization and/or more state control. We also observe a stronger role of the state regarding the provision of child care and of female friendly leave policies, albeit with a strong emphasis on 'free choice' on the part of dual earner families. The state is not to interfere directly in family life.

\section{Modernization pains across southern welfares state under fiscal austerity}

The modernization of southern welfare states proved particularly difficult, as external pressures from the entry into EMU and intensified economic internationalization combined with the rapid aging of the population and fierce social opposition against reform from a range of vested interests. Yet southern European states pursued an ambitious agenda of reform, including the attenuation of overly generous guarantees for privileged occupational groups, improved minimum benefits, the introduction and consolidation of safety nets, especially through means-tested minimum income schemes, increased family benefits and social services, measures against tax evasion, the reform of labor markets and the modification of unemployment insurance benefits.

Italy saw a rapid growth of expenditures on public pensions after generous social security reforms in the 1970s. Deficits soared and by the early 1980s, escalating inflation made a reorientation of macroeconomic policy inevitable. By the late 1980s Italy was becoming a 
'pension state'. But proposals to rationalize the pension system and restore financial balance led only to incremental cuts and little progress. The Maastricht criteria for EMU membership subsequently made fiscal restraint indispensable, and also helped spur policy reforms in industrial relations, social security and labour market regulation (Ferrera and Gualmini 1999). Within the pension system, the privileges enjoyed by civil servants to retire after only 20 years of service regardless of age (the so-called baby pensions') was phased out. Pension rights were accorded to atypical workers, and lower pensions were repeatedly upgraded. Some traditional gaps in social coverage were also filled. The introduction of means-tested maternity benefits for uninsured mothers was accompanied by a reform of parental leave, and a means-tested allowance for families with three or more children was introduced. But little progress has been made in improving the functioning of the Italian labour market: rigid norms protecting the employed have only been relaxed marginally, and Italy's system of wage guarantees and unemployment compensation schemes has not been reformed. As the combination of labour shedding policies, low female participation and low birth rates were exacerbating the pension crisis similarly as in other Mediterranean countries, the Prodigovernment did recognize that caring services and leave arrangement, especially for families with small children and for the aged, are an urgent matter, but reform on these issues has been blocked by political contestation.

With respect to care, leave and social services, Spain is much more of a front runner today (Guillen, Álvarez and Adão e Silva, 2003). When Spain joined the EC in 1986 it had a highly regulated labour market, but only a rudimentary system of social provision. In the recession of the early 1990s, unemployment rose to almost 25 per cent, producing a sharp increase in unemployment compensation payments and a severe deterioration in public finances. In 1995, with an eye on early EMU entry, the government, unions and employers agreed to the Toledo Pact that sanctioned pensions and labour market reform. With trade union consent, cuts in pension benefits for the better off' were traded for improving the positions of lowerincome earners. Spain also engineered a thoroughgoing decentralization in social services from central government to the regions. Regarding unemployment, reforms included new flexible contracts (which, however, led to an explosion of temporary employment), a rationalization of unemployment benefits, activation measures, and broad changes in employment services (Moreno, 2000). Unlike Italy, Spain has also progressed towards reducing inequalities in the labour market: in 1997, 2001 and 2005, labour laws relaxed the protection for core employees and improved the social security rights of irregular and temporary workers. Unemployment fell from 24 per cent in 1994 to 8.5 per cent in 2006 and is now lower than in Germany or France. Like Spain, Portugal improved its minimum benefits in pensions, increased family allowances, as well as the basic safety net and 
experimented with minimum income schemes. Unemployment insurance was broadly reformed, occupational training and insertion programs were expanded, and specific incentives were introduced to promote a 'social market for employment' based on local initiatives that targeted the most vulnerable workers.

Anglo-Irish diverging Third Ways'

The picture of the 'Anglo Saxon model' producing high levels of inequality is certainly true from the mid-1970s to the mid-1990s, when income inequality rose dramatically, further and faster than in almost any country in the world. In the United Kingdom, Westminster-style government (giving the governing party with a significant majority untrammeled decisionmaking powers) allowed Conservative governments in the 1980s and 1990s to speed up social security reform. Benefits eroded in real value and the middle classes were encouraged to opt out into non-public forms of insurance in pensions and health care. As the costs of targeted, means-tested benefits started to soar despite a tightening of eligibility rules inspired by the new 'workfare' philosophy, a stricter benefit regime contained costs by reducing the number of claimants. These developments have had significant consequences. The erosion of universal provision has helped restore public finances, radical labor market deregulation has fostered an expansion of private employment, and inequality and poverty have markedly increased, partly because of the perverse effects of means-testing (Rhodes, 2000).

After 1997 the Blair government embarked on a broad strategy of 'third way' reform, finetuning benefit rules to neutralize the 'traps' created by welfare-to-work schemes, and launching a fight against poverty and social exclusion by increasing minimum wage and income guarantees, reforming the tax code and introducing new targeted programs. Much like the Conservatives before them, New Labor's approach has been to minimize regulatory burdens on the labor market, but its 'welfare-to-work' strategy differs substantially from its predecessor's workfare policies. The New Labour approach has been built around a 'rights and responsibilities' agenda that attaches conditions to benefits, requiring the unemployed to actively seek work and training. That has been matched, however, by more generous in-work benefits for those who take low paid jobs, a policy now underpinned by a minimum wage. The most distinctive feature in New Labour's strategy of welfare reform is reliance on work and employability to address poverty, disadvantage, and social exclusion. In part, reforms were inspired by the active labor market policy tradition of the Nordic countries. In 1997, the Blair government introduced the New Deal for skills and compulsory job search aimed at moving especially young workers from public benefits into employment (Clasen, 2005). New Deal activation programs rely heavily on tax credits, which have gained in importance, particularly since the introduction of the Working Families Tax Credit (WFTC) in 1998, 
aimed at guaranteeing any family with a full-time worker a relatively generous minimum income (Glyn and Wood, 2001). A national minimum wage was introduced from 1999, set at different levels for different age groups, and has been regularly raised since. However, in contrast to 'third way' rhetoric about learning and education as the key to prosperity', vocational training, skill enhancement, and upward mobility are rather limited. Since the mid-1990s the trend towards higher inequality and poverty, although still high, has been halted, in part due to the introduction of a wide range of new tax credits.

In the late 1970s and early 1980s, the Irish mimicked British decentralization of wage bargaining and radical labor market deregulation. The United Kingdom and Ireland have parted company over the last twenty years. Instead of following the UK's path of restricting union power, Irish governments have adopted a more coordinated strategy based on successive 'social pacts', also to qualify for EMU. Beginning with the National Recovery accord of 1987-1991, cooperation with business and unions helped reform the economy and attract high levels of foreign direct investment, boosting Ireland's rates of output and employment growth. The revitalization of the Irish economy is also based on increased investments in education, preventing early departure from formal education and training, and facilitating the transition from school to work, in particular school leavers with low qualifications (NESC, 2005). Poverty levels, however, did not initially decrease, principally because transfers per recipient, although rising significantly in real terms, lagged behind the exceptionally large increases in average income. Therefore, while there are fewer people relying on transfers as unemployment has declined, more of those reliant on them are relatively poorer. However, research does reveal a marked decline in poverty from 1994 (Nolan et al, 2000).

Recalibrating welfare in Europe's new member states

Since the fall of the Berlin wall, Central and Eastern European welfare states have been a laboratory of social policy experimentation, and as a result they have remained underdefined. Characteristic of the transformation of the welfare state in Central and Eastern Europe has been the extended role for international organizations, like the World Bank and the IMF, especially in the area of old-age pensions. For most of the 1990s, the role of the EU in shaping social policy in the region was comparatively weak. Only since the new Millennium has the EU started to push social policy issues on the political agenda of CEE countries. In May 2004, the Czech Republic, Estonia, Hungary, Latvia, Lithuania, Poland, Slovakia, and Slovenia, became the first eight post-communist Central and Eastern European economies, to become fully-fledged members of the European Union. While participating in 
the Lisbon Strategy, there has been a growing interest in the New Member States (NMS) in the institutional structure and quality of social policies and services.

The collapse of state-socialism and the (re-)establishment of capitalism in 1989-1991 were accompanied by a deep economic crisis. In 1990-1994, economic growth and wages declined rapidly and inflation spiraled, bringing an end to full employment, with job losses ranging from 10 percent in the Czech Republic to 30 percent in Hungary. Unemployment rose from virtually zero to two-digit levels rates in countries like Poland, Slovakia and Lithuania. Since 1995, the CEE economies have been growing again, as have real wages, but employment rates remained extremely low in Hungary, Slovakia and Poland (Hemerijck/Keune/ Rhodes, 2006).

The first decade of welfare transformation in Central and Eastern Europe saw the withdrawal of the state from the economy. In the early post-1989 period, the welfare state was used as a buffer to cushion the most dramatic effects of economic crisis and reform, especially the loss of income through unemployment. Early retirement provisions and disability pensions were widely used for redundant workers (Fultz and Ruck 2001; Müller 2002). Most CEE countries introduced a minimum wage and income-related social assistance schemes to combat poverty. However, inflation often depleted the real value of social benefits, leading to increasing poverty, not only among the old, but also among children,except for Slovenia and the Czech Republic. As an ethnic group, the Roma suffered the most from the social and economic hardship (Potucek, 2007).

As the number of people on pension, unemployment or social assistance benefits increased dramatically, this led to a near fiscal crisis by the mid-1990s in most CEE countries. A new wave of reform took shape, -- with a view to containing costs and reducing welfare (Keune, 2006). As elsewhere, welfare reform was heavily contested. Cost containment was achieved by tightening unemployment benefits, and the duration of benefits and replacement rates were reduced. Pension reform - particularly privatization and the individualization of savings - was also strongly advocated by the World Bank. State-socialist old-age pension systems were largely financed on a pay-as-you-go (PAYG) basis through transfers from state firms to the state budget; direct contributions by workers themselves were rare (Fultz and Ruck, 2001). The introduction of the mandatory second tier of old age pension schemes run by private funds, in Hungary in 1998, Poland in 1999, Latvia in 2001, Estonia in 2002, and Slovakia in 2003, represents a clear indicator of the success of the World Bank's advocacy for pension privatization. The Czech Republic has thus far resisted the shift to compulsory private co-insurance, because the Czech economy was not in as deep a fiscal crisis as many of 
the other CEE countries and therefore less dependent on loans provided by the IMF and the World Bank, but also due to strong domestic political opposition from the ruling social democratic party and the trade unions. In 1995 the Czech government did agree to raise the statutory retirement age incrementally for women to 57-61 (the actual limit depending on the number of children) and for men to 62 up until 2007 (Potucek, 2007).

Passive labor market policies still account for over half of all labor market spending in the CEE countries. Active labour market policies are relatively well developed in Hungary and Slovenia, while in the Czech Republic the attention paid to active and passive employment policy has fluctuated over the years according to the political colors of government, with social democrats more in favor of active policies and neo-liberal parties more supportive of passive programs. Family and child care policies, maternity benefits, constituted a prominent example of state-socialist welfare provision in most CEE countries. Traditional forms of public support for families with children weakened considerably during the transformation period. In Hungary, earnings-related maternity benefits were entirely abolished to be replaced by flat-rate benefits which were linked to the level of the minimum pension. The provision of child care and kindergartens was at least partially re-commodified in the Czech Republic. Family cash support dropped as well, with the important exception of Slovenia. Targeted, means tested residual schemes were introduced in child allowances in the Czech Republic.

All post-communist welfare states have evolved towards a hybrid mixture of conservative and liberal regime types, with a flavor of limited universalist elements. In many of the NMS the new social policy repertoire seem to be crystallizing around three tiers, containing a compulsory Bismarckian social insurance, financed out of contributions, active labour market policies and public social assistance financed from general taxation, but run by local authorities. While the Visegrad countries have in important measures returned to their roots of Bismarckian social insurance from the late $19^{\text {th }}$ century, the Baltic nations have seen a greater emphasis on means-testing and targeting.

\section{THE RELATIVE SUCCESS OF THE EUROPEAN EMPLOYMENT STRATEGY}

Neither the doomsday scenario of the demise of the European welfare state, predicted by OECD economists, nor the prevailing image of a 'frozen welfare status quo' can be corroborated by the European welfare reform experience highlighted above. Over the past two decades, as the above inventory of reform shows, many European welfare states have with varying degrees of success - taken measures in order to redirect economic and social 
restructuring by pushing through adjustments in macro-economic policy, industrial relations, taxation, social security, labor market policy, employment protection legislation, pensions and social services, and welfare financing. The result has been a highly dynamic process of "self-transformation of the European social model(s)" (Hemerijck 2002), marked not by half-hearted retrenchment efforts but by more comprehensive trajectories of "recalibration", ranging from redesigning welfare programs to the elaboration of new principles of social justice. (Ferrera, Hemerijck and Rhodes, 2000; Ferrera and Hemerijck, 2003). Many reforms were unpopular, but a fair amount occurred with the consent of opposition parties, trade unions, and employer organizations. In the process we have seen the rise and fall, respectively, the Swedish model macroeconomic management of the 1970s and the German model of diversified quality production of the 1980s. In the 1990s, the Dutch employment miracle played a prominent role in discussions about the possibilities for a new "capitalism with a social face" in an age of global competition, industrial restructuring and ageing populations. Today the Celtic Tiger, the Danish 'flexicurity' golden triangle, the Finnish knowledge economy figure as model countries to emulate.

While we observe significant policy change in most welfare states in the European Union, we have not seen brutal departures, except for the UK in the 1980s, from regime-specific historical origins. Rather we note more incremental transformative processes of sequential and cumulative policy adjustment across adjacent policy areas, with one reform building on the success and shortcomings of previous policy changes (Hemerijck and Schludi, 2000; Streeck and Thelen, 2005; Bonoli and Palier, 2007).

Underneath these dynamic sequences of reforms we do, however, observe a remarkable "convergence" of employment and social policy objectives and outcomes, the adoption of increasingly similar policy initiatives, encouraged also by the deepening of the EU social agenda. In the changed endogenous policy environment of the 1990s it became clear that the active service-oriented welfare states were in a stronger position than the passive, transferoriented systems to make adaptations to the challenge of the feminization of the labor market. In labour market policy, the new objective became maximizing employment rather than inducing labour market exit, and this implied new links between employment policy and social security, triggering a change from passive policy priorities aimed at income maintenance towards active policy priorities aimed at activation and reintegration of vulnerable groups together with a strengthening of minimum income provisions. In the area of old-age pensions, the most important trend is the growth of compulsory occupational and private pensions and the development of multi-pillar systems with a tighter actuarial link between benefits and contributions. 
Spending on childcare, education, health, and elderly care, next to training and employment services, has increased practically everywhere over the past decade. Throughout the EU, leave arrangements have also been expanded, both in terms of time and in the scope of coverage, to include care for the frail elderly and for children. All European welfare states are in the process of moving away from the breadwinner/caregiver model, under which mothers are expected to stay home with children, to a dual earner model, under which mothers are expected to enter the labor force. This transition is not merely the product of changing gender values; it is also part of a more deliberate strategy of policymakers to confront population ageing by attracting mothers into the work force through activation programs, tax subsidies, part-time employment regulation, and the expansion of family services, also to reverse falling levels of fertility (Orloff, 2006).

With respect to financing, we observe an increase in user financing in the areas of child care, old age care, and medical care. At the same time, fiscal incentives have been introduced to encourage people to take out private services and insurance, especially in the areas of health and pensions. In many Continental welfare states targeted benefits are increasingly financed through taxation and general revenues rather than social charges, whereas in Scandinavian countries contribution financing has been growing, especially in the area of pensions. As a result of intensified competition across the European Union, many EU Member States have started to pursue a hybrid strategy of lower statutory tax rates and a broadening of the tax base. Some of the NMS have gone as far as to introduce flat taxes. This implies a shift away from a focus on vertical redistribution between rich and poor citizens, but not necessarily a shift away from prevailing welfare commitments.

Since the mid-1980s domestic issues of work and welfare have become ever more intertwined with processes of European political and economic integration. The introduction of the internal market and the introduction of the EMU, and Stability and Growth Pact, have added a new economic supranational layer to domestic social and economic policy repertoires of individual Member States. Since the mid-1990s, the EU has taken on a far more pro-active role as a central social policy agenda setter. The European Employment Strategy, based on the new Employment Title of the Amsterdam Treaty, launched in 1997, is exemplary of the EU's new role of agenda setting policy coordination, designed to catalyze rather than steer domestic social policy reform. Under the EES, respecting the principles of subsidiarity and proportionality, member states conduct their own policies but they are required to expose their policy experiences to common analyses and peer-group evaluation. In the absence of binding sanctions, social learning, discursive diffusion, comparing best practices, monitoring 
progress with specific timetables and reporting mechanisms, together with peer pressure, in light of common goals and objectives, serve to expose national policy makers to a new definition of the employment problems social policies are meant to be address.

A comparison between the European Employment Strategy and the original OECD Jobs Strategy, with which we started our contribution to this volume, reveals one similarity and a number of important differences. Both reform campaigns abide by a supply-side diagnosis of the labor market. While in 1994, the OECD J obs Strategy was met with lukewarm support and fierce opposition, we believe that the EES, being more cautious and less confrontational, has proven to be more effective in helping national policy makers to translate new labour market and social policy ideas into action.

Whereas the OECD J ob Strategy focused on fighting unemployment, applying the concept of NAIRU (non-accelerating inflation rate of unemployment) as a benchmark, the EES is more bent on raising the share of employed persons within the population as the key to comparative employment performance. The Lisbon summit of 2000 set target employment rates: By 2010, 70\% of the EU population aged 15-64 should be in paid employment, with $60 \%$ of women. The Stockholm summit of 2001 complemented these with intermediary targets for 2005 and added a target for older workers (aged 55-64), namely 50\% in 2010.

A second important difference between the two strategies is that the original OECD J obs Strategy was based on a rather deductive and distinctly efficiency-oriented form of policy analysis, drawn up by the leading economists of the OECD. The EES, by contrast, followed a more inductive approach. But what is more critical is that policy analysis within the context of the EES is not a product of academic expertise, but rather a joint endeavor of domestic policy-makers, civil servants, the European commission, and other interested parties. The result is a more inclusive, albeit fuzzy, process of EU member state commitment, with a better chance of amplifying or intensifying reform. Due to the more 'contextualised' (Hemerijck/Visser, 2003) quality of the open method of coordination (OMC) to come to recommendations, the EES is particularly emphatic to processes of contingent convergence.

We maintain that the key contribution of the EES to improved labor market performance is mainly cognitive, but not as an afterthought, but as its major feat. The EES helped to redefine the European employment problem away from managing unemployment toward the promotion of employment, fostering the diffusion and acceptance of a new mental framework for employment policy re-direction rather than concrete policy recommendations. We believe that the reorientation from managing unemployment to promoting employment, on the basis 
of activation, active ageing/ avoidance of early retirement, part-time work, lifelong learning, parental leave, gender mainstreaming, flexicurity, balancing flexibility with security, reconciling work and family life, is of a similar magnitude as the macroeconomic paradigm shift from Keynesianism to monetarism of the early 1980s. This surely was also the stronghold of the OECD Jobs Strategy. But while the OECD 'one-size-fits-all' recommendations ran the risk of intensifying rather than narrowing the ideological rift between policy makers from Anglo-Saxon and the Rhineland and Nordic member countries of the OECD, the EES's more consensual approach, plausibly seem to have been far more effective in stimulating changes in policy thinking, also by deliberately shying away from single minded policy recommendations. This, ironically, has resulted in narrowing rather than widening the real divergence across EU welfare states in policy and outcomes. The OECD itself, in turn, adopted a more subtle approach reflecting much of the policy interactions and balancing flexibility and security in the restated Job Strategy from 2006 (OECD 2006a).

Practically parallel to and stimulated by the development of a new labor market policy paradigm, the EU, through with a series of agenda-setting EU presidencies, has in past half a decade come to conceptualize a fairly coherent new narrative about how vital a role social policy has to play in the new era of economic internationalization and post-industrial social change. While the architects of the post-war welfare state, John Maynard Keynes and William Beveridge, could assume stable male-breadwinner families and expanding industrial labor markets, this picture of economy and society no longer holds. In order to connect social policy more fully with a more dynamic economy and society, EU citizens have to be endowed with capabilities, through active policies that intervene early in the life cycle rather than later with more expensive passive and reactive policies (Esping-Andersen et al, 2002). At the heart of the new narrative lies a re-orientation in social citizenship, away from freedom from want towards freedom to act, prioritizing high levels of employment for both men and women as the key policy objective, while combining elements of flexibility and security, under the proviso of accommodating work and family life and a guaranteed rich social minimum serving citizens to pursue fuller and more satisfying lives. 


\section{REFERENCES}

Aiginger, K. and A. Guger (2006), The European Socioeconomic Model, in: A. Giddens, P. Diamond and R. Liddle (eds.). Global Europe, Social Europe, PolityPress, Cambridge, pp. 124-150;

Alber, J . (2008) Employment Patterns in the Enlarged EU, in: Alber, J./Saraceno, Ch. And T. Fahey (eds.), Handbook of Quality of Life in the Enlarged European Union, London/New York: Routledge, pp. 129-161;

Alber J . (2006) The European Social Model and the United States", in: European Union Politics 7, pp. 393-419.

Allmendinger (this volume)

Andersen, T.M. and M. Svarer (2007), Flexicurity - Labor Market Performance in Denmark. CESifo Working Paper 2108;

Bonoli, G. and B. Palier (2007), When Past Reforms Open New Opportunities. Social Policy and Administration 41(6): 555-573;

Castles (this volume)

Clasen, J. and D. Clegg (2006), Beyond Activation: Reforming European Unemployment Protection Systems in Post-Industrial Labour Markets. European Societies 8 (4): 527-553

Clasen, J. (2005), Reforming European Welfare States: Germany and the United Kingdom Compared, Oxford: Oxford University Press.

Eichhorst, W., M. Grienberger-Zingerle and R. Konle-Seidl (2008): Activation Policies in Germany: From Status Protection to Basic Income Support, forthcoming in: German Policy Studies 2008.

Erhel, C. and B. Gazier, Flexicurity and beyond: micro-macro aspects of transitions management in the European employment strategy, Preparatory Workshop on the employment guidelines, Lisbonne, 25 mai 2007 (revised version, J une 2007);

Esping-Andersen, G. (1990), The Three Worlds of Welfare Capitalism. Cambridge: Polity Press;

Esping-Andersen, G. (1999), Social Foundations of Post-industrial Economies. Oxford, Oxford University Press;

Esping-Andersen, G., D. Gallie, A. Hemerijck and J . Myles, (2002), Why We Need a New Welfare State, Oxford: Oxford University Press;

Ferrera, M. (1996), The Southern Model of Welfare in Social Europe', J ournal of European Social Policy, vol. 6(1), pp. 17-37.

Ferrera, M. (2005), The Boundaries of Welfare: European Integration and the New Spatial Politics of Solidarity, Oxford, Oxford University Press (forthcoming);

Ferrera, M., A. Hemerijck and M. Rhodes (2000), The Future of Social Europe: Recasting Work and Welfare in the New Economy, Oeiras, Celta Editora;

Ferrera, M. and A. Hemerijck (2003), 'Recalibrating Europe's welfare regimes', in in J. Zeitlin D.M. Trubek (eds.), Governing Work and Welfare in the New Economy. European and American Experiments, Oxford: Oxford University Press;

Ferrera, M. and E. Gualmini (1999), Salvati dal Europa, Milan: Il Mulino;

Fultz, E. and Ruck, M. (2001) 'Pension Reform in Central and Eastern Europe: Emerging Issues and Patterns,' International Labour Review, Vol. 140(1), pp. 19-43.

Gilbert, N. (this volume) 
Glyn, A. and S. Wood (2001), 'New Labour's Economic Policy', in A. Glyn (ed.), Social Democracy in Neoliberal Times. The Left and Economic Policy since 1980, Oxford: Oxford University Press, pp. 200-222.

Guillén, A., S. Álvarez and P. Adão E Silva (2003), 'Redesigning the Spanish and Portuguese Welfare States: The Impact of Accession into the European Union', South European Society and Politics, Vol. 8(1-2), pp. 231-268.

Hemerijck, A. and P. Manow (2001), The Experience of Negotiated Reforms in the Dutch and German Welfare States, in: Ebbinghaus, B. and P. Manow (eds.), Comparing Welfare Capitalism. Social Policy and Political Economy in Europe, J apan and the USA. London, Routledge, pp. 217-238;

Hemerijck, A. (2002), The self- transformation of the European social model(s)', in G. EspingAndersen with D. Gallie, A. Hemerijck and J. Myles (2002), Why we Need a New Welfare State, Oxford: Oxford University Press;

Hemerijck, A. (2006), 'Social Change and Welfare Reform', in: A. Giddens, P. Diamond and R. Liddle (eds.). Global Europe, Social Europe, PolityPress, Cambridge;

Hemerijck, A. and M. Schludi (2000) 'Sequences of Policy Failures and Effective Policy Responses', in F. W. Scharpf and V. Schmidt (edss), Welfare and Work in the Open Economy - From Vulnerability to Competitiveness, Oxford, Oxford University Press;

Hemerijck, A., M. Keune and M. Rhodes (2006), 'European Welfare States: Diversity, Challenges and Reform', in: P. Heywood, E. J ones, M. Rhodes and U. Sedelmeier, Developments in European Politics, Houndmills, Palgrave;

Hemerijck, A. and J . Visser (2003), Policy Learning in European Welfare States, manuscript, University of Amsterdam;

Immergut, E.M, K. Anderson and I. Schulze (eds.) (2007), The Handbook of West European Pension Politics, Oxford, Oxford University Press;

Kenworthy, L. (2004), Egalitarian Capitalism. J obs, Incomes, and Growth in Affluent Countries, New York: Russel Sage Foundation;

Keune (2006) 'The European Social Model and Enlargement', in M. Jepsen and A. Serrano (eds.) Unwrapping the European Social Model, Bristol: Policy Press.

Kornai, J. (1992) The Socialist System: The Political Economy of Communism, Oxford: Oxford University Press.

Kuhle, S. (2000), The Scandinavian Welfare State in the 1990s: Challenged but Viable', in West European Politics, vol. 23, no. 2.

Leibfried, S. and P. Pierson (2000), 'Social Policy', in: H. Wallace and W. Wallace (eds.), Policy Making in the European Union, $4^{\text {th }}$ edn., Oxford: Oxford University Press: 267-291;

Lindert, P.H. (2004), Growing Public: Social Spending and Economic Growth since the Eighteenth Century, Cambridge: Cambridge University Press;

Moreno, L. (2000), The Spanish Developments of the Southern Welfare State', in S. Kuhnle (ed.), Survival of the European Welfare State, London, Routledge, pp. 146-165.

Müller, K. (2002) 'Pension Reform Paths in Central-Eastern Europe and the Former Soviet Union', Social Policy and Administration, Vol. 36, No 2: 725-748.

National Economic Social Council (NESC) (2005), The Developmental Welfare State, The National Economic Social Council, Dublin nr. 113, May 2005

Nolan, B., P.J . O 'Connell and C.T. Whelan (2000), Bust to Boom: The Irish Experience of Growth and Inequality, Dublin: Institute of Public Administration.

OECD (1994), The OECD Jobs Study. Paris: Organisation for Economic Co-operation and Development, 1994;

OECD (2005), Promoting Adult Learning, Paris: OECD

OECD (2006a), OECD Employment Outlook, Paris: OECD

OECD (2006b), PISA 2006 Science Competencies for Tomorrow's World, Paris: OECD

OECD (2007a), OECD Employment Outlook, Paris: OECD 
OECD (2007b), Babies and Bosses. Reconciling Work and Family Life, Paris: OECD

Orloff, A.S. (2006), Farewell to Maternalism', in: J.D. Levy (ed.), The State After Statism, Cambrdige Ma., Harvard University Press;

Pierson, P., (1998), 'Irresistible Forces, Immovable Objects: Post-Industrial Welfare States Confront Permanent Austerity'. J ournal of European Public Policy, 5/ 4: 539 - 560;

Pierson, P. (ed.) (2001), The New Politics of the Welfare State, Oxford, Oxford University Press;

Potucek, M. (2007), 'Welfare Transformations in Central and Eastern Europe', Prague Social Science Studies, Faculty of Social Sciences/Faculty of Arts, Charles University, Public Policy and Forecasting PPF - 023.

Rhodes, M. (2000), 'Restructuring the British Welfare State: Between Domestic Constraints and Global Imperatives', in F. W. Scharpf and V. Schmidt, eds., Welfare and Work in the Open Economy: Diverse Responses to Economic Challenges, Oxford: Oxford University Press, pp. 19-68.

Rhodes, M. and M. Keune (2006) 'EMU and Welfare States in East Central Europe', in: Dyson, K. (ed.) Enlarging the Euro-Zone: The Euro and the Transformation of East Central Europe, Oxford: Oxford University Press.

Scharpf, F.W. and V.A. Schmidt (eds.) (2000), Welfare and Work in the Open Economy, 2 Volumes, Oxford, Oxford University Press.

Schludi, M. (2005), The Reform of Bismarckian Pension Systems: a Comparison of Pension politics in Austria, France, Germany, Italy and Sweden, Amsterdam: Amsterdam University Press.

Streeck, W. and K. Thelen (2005), Introduction: Institutional Change in Advanced Political Economies, in: Streeck, W. and K. Thesen (eds.) Beyond Continuity. Institutional Change in Advanced Political Economies. Oxford: Oxford University Press, pp 1-39;

Visser, J ./ Hemerijck, A. (1997), 'A Dutch Miracle': J ob Growth, Welfare Reform and Corporatism in the Netherlands, Amsterdam, Amsterdam University Press;

Zeitlin, J. (2005), The Open Method of Coordination in Action: Theoretical Promise, Empirical Realities, Reform Strategy', in: J . Zeitlin and P. Pochet (eds) (2005), The Open Method of Coordination in Action; The European Employment and Social Inclusion Strategies, Bruxelles: SALTSA, P.I.E.-Peter Lang, pp 447-503. 